\title{
Corporate reporting: how words add value - By:
}

GABRIELE MOLL

Posted by Michael Lambarena on February 262009 13:45:22

\section{Corporate reporting: how words add value}

The primary function of corporate reporting is to provide investors with information. However, these days, companies are also recognising the media value of the annual report, which is the main vehicle of corporate reporting, and are concluding that it's an efficient means of communication between the business and their stakeholders. Corporate reporting also assists in building image. Additionally in recent years there has been an increasing trend in value reporting, which can be defined as: a new form of reporting where words are as important as figures.

"Continuing long-established methodologies may be a virtue in winemaking, performance of classical music, and safeguarding human rights as political ideas. In contrast, maintaining the status quo in financial reporting is a sure recipe for disaster."[1] These are the words of Gerhard G. Mueller, a professor of accounting in the United States. Mueller's colleague William Beaver[2] goes even further, proclaiming for an "accounting revolution".

Both professors criticise what they see as an outdated form of reporting that refers only to the past. This form of reporting describes events occurring in preceding business years, namely balance sheets, profit and loss statements. This particular system used - double entry accounting - is more than 500 years old, and traces its origin back to a mathematician and Franciscan monk called Luca Pacioli.

\section{The accounting revolution}

The first time Mueller and Beaver voiced their criticism was at the end of the 1990s. Subsequently, a lot of action has been taken within the world of financial reporting, enabling stakeholders with the benefit of greater transparency. In Europe, the International Financial Reporting Standards (IFRS) have been implemented for all stock-exchange-listed companies since 2005. Corporate and accounting scandals at prestigious companies such as Enron, WorldCom and Parmalat reverberated around the world, provoking drastic regulatory measures. 
In July 2002, the United States introduced the Sarbanes-Oxley Act, a stringent piece of legislation containing thorough new rules on corporate management, reporting and auditing. The aim was to substantially boost the quality and transparency of financial reporting, strengthen auditor independence, and to ensure a rigorous audit.

The Sarbanes-Oxley Act triggered a veritable accounting and auditing revolution - not just in the United States, but globally. Currently companies and auditors are facing global regulatory pressure. Modern financial reporting standards have made corporate reporting much more transparent for financial analysts, institutional investors and banks, therefore allowing the performance of companies to be analyzed over time and across industries. The disadvantage of this is that financial statements are now so detailed and complex that only experts are able to interpret them.

However, by definition, communication should be understandable. Thus, the accounting revolution has to be accompanied by a reporting revolution. The watchword of this revolution is value reporting. The principal goals of value reporting is to transform a backward-looking account of a company's finances into a forwardlooking account of its business and the factors that are driving it now and in the future.

Investors, financial analysts and the public have a greater need for information than they did, twenty years ago. The type of information they're looking for is different too. For example, stakeholders now demand future-oriented information on strategies; market positions, investment and R\&D. Stakeholders expect companies to report more openly on social and environmental responsibility. The financial world demands a detailed insight into a company's finances and strategy in order to make the right investment decisions.

\section{The reporting revolution}

In addition to giving investors a clear picture of the company's finances, the annual and quarterly report, together with the company websites - can help build stakeholder trust. However, companies have to question precisely which information their various stakeholders require. This is where value reporting comes in.

Value reporting is a new form of reporting that includes forwardlooking and non-financial information. Examples of forward-looking 
information include; details of the company's proposed capital expenditure, returns it expects on this investment; details of intended costs on staff training. In other words this is precisely how this money will be invested; or examples to illustrate the organisation's power of innovation. Relevant non-financial information may include details of the company's customer structure, an assessment of customer satisfaction, a profile of the company's staff (as an indication of employee commitment), and a description of how the organisation has maintained their structural processes and management.

Value reporting makes investment planning and the management information system an integrated part of the financial statements, and provides stakeholders with an idea of what the company's most important objectives are, and to what extent can it manage value to achieve these targets. Value reporting is thus a form of publicity that, unlike a traditional backward-looking annual or quarterly report, gives an insight into the way business will develop and move forward. The aim is to provide investors with all the information they need, in order for them to make the right investment decisions. This also means providing background information on products (for example innovative new products, the expiration of important patents, the way margins are developing), markets (which may include industry developments, an analysis of the competition, or an assessment of the company's market position), strategic success factors (such as core competencies and know-how in specific areas) and corporate governance. In its report, management must analyse trends and explain changes in the financial statements and investment portfolio. This type of qualitative information is designed to help the reader interpret the quantitative information contained in the report and place the company in the context of the industry in which it operates.

\section{The Value Reporting Framework}

The concept of value reporting was shaped by the auditing and advisory firm PricewaterhouseCoopers. In 1997, advisors Philip D. Wright and Daniel P. Keegan published a small but visionary brochure on the art of reporting on the future. In the introduction they say:

"In the 1990s, a new view of shareholder value is taking root in the minds of executives and investors in many parts of the world - and a new type of reporting is emerging. We call it value reporting (VR). In essence, value reporting focuses on long-term cash - i.e., cash that will come through the company's door at some future date and other types of performance information that impact shareholder 
wealth, the company's prospects, and the financial markets' assessment of the company. The discipline of VR promises to integrate the principles of traditional financial reporting, investment reporting, and management reporting."[3]

Since the publication of this brochure, PricewaterhouseCoopers has regularly consulted financial analysts and institutional investors to find out what they view as the most important information for making investment decisions. Research has shown that the most interesting information for them is the information that management needs to direct the business. Therefore it follows that value reporting should be based on the internal information utilized by the company's management. On the basis of survey findings and academic research into value-driven management, PricewaterhouseCoopers have developed the ValueReporting ${ }^{\mathrm{TM}}$ Framework, a model enabling a consistent yet complex picture to be painted of a company in the medium term.

The framework consists of four levels, each of which has an influence on those that follow. The report starts with a market overview. The dynamics of the external operating environment, the macroeconomic and regulatory environment, and the competitive situation within the industry. These typically exert significant influence on a company's strategic options, current performance, and future prospects. For this reason it is the logical starting-point for the reporting framework.

\section{Corporate Reporting Framework}

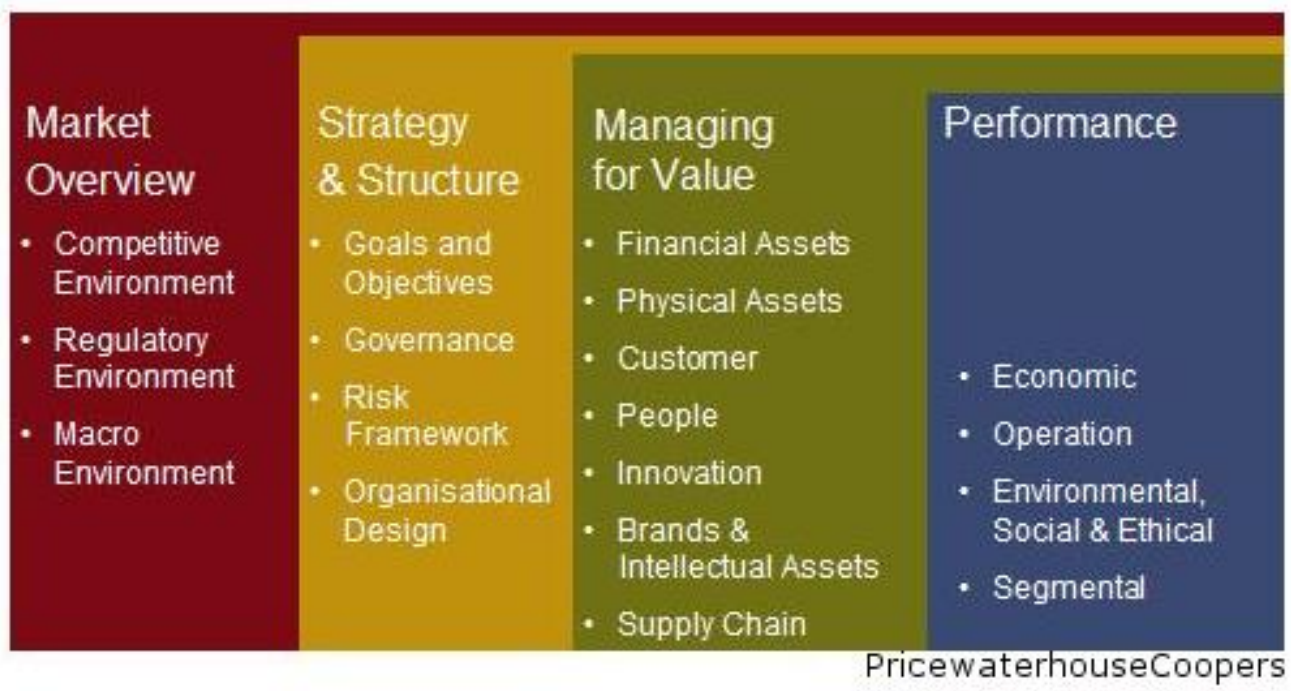

Subsequent to this market overview, the next level of the reporting framework describes and explains the company's structure and 
strategy. A company has to define its strategy within the context of its economic and regulatory environment. Structures must enable the company to function and succeed in any given competitive situation. These factors should be communicated in its reporting alongside strategic objectives and risk policies for the organisation as a whole and for specific areas of its business.

Since managing for value must always be done in the light of the company's strategic objectives, the next consecutive step is to describe the management and quantify the value drivers of the business. To execute its strategy, an organisation must identify, manage and disclose the factors that have the greatest influence on its performance and that have contributed to its professional success. Businesses operate in a complex web of relationships between clients, business partners, suppliers and staff, processes that make up the value chain, and the control mechanisms set up to monitor these processes - all of which can potentially be important drivers of value. While the factors that actually drive a particular business depend to a significant extent on the industry in which it operates, customers, people and the brand are always key value drivers.

Finally, the fourth level describes performance, in other words the results of the company's efforts in the management for value. Ultimately the company's results - both financial and non-financial are the litmus test of its strategy, structure and value management; an implicit indication of how well management has understood its market, executed its strategy, and managed its value-creating resources and relationships.

The ValueReporting ${ }^{\mathrm{TM}}$ Framework has two key advantages. It is flexible enough to be adapted to the environments of different industries, yet it still manages to provide enough scope for describing, explaining and interpreting a company's business and performance.

\section{$\underline{\text { Facts }}$}

\section{No room for empty words in management reports}

Management reports have to say something meaningful; they have to contain concrete facts, interpretations and assessments. What they should not contain is empty words and phrases that could have been copied from some other business report.

Definitely no-no is the kind of throwaway statement found in just about any annual report you care to look at: "We deliver services that benefit our customers." "We create customised solutions 
tailored to the individual needs of our clients." "Our people are our most important asset." "We do everything in our power to add value for our shareholders." "We take our responsibility to society seriously." These are empty words that do little to enhance the image of the company, and fail to give the reader any insight whatsoever into its strategy or value management. They merely gloss over the fact that the management is either unable or unwilling to formulate a meaningful statement. In both cases it would be better to say nothing.

In fact these statements are not only devoid of content, they're dishonest too. Companies should have the courage to admit what everybody knows anyway: their sole aim is to earn as much profit as possible. Naturally this can only happen if customers are satisfied with their products and services, staff stay loyal and keep their know-how in the company, and shareholders don't take their money elsewhere. A management report really isn't the place to air this kind of business platitude.

Your readers are interested in other things: Did we attain our strategic objectives? If so, how? If not, why not? What are we doing to strengthen our company's position in the market? How do we differentiate ourselves from the competition? How does management see things developing in future? These are the sort of pithy, practical statements - underpinned by figures - that distinguish a good management report.

Glossing things over, by contrast, is counterproductive. The real villain is that harmless looking little word "even". Look at most annual reports and you'll see that processes have been made even more efficient (instead of just more efficient), and staff aren't more satisfied, they're even more satisfied. The idea is that without the word "even", people might think that processes weren't efficient before, and that staff weren't satisfied. But this linguistic trick is so transparent that it's better to leave it out altogether.

Writing a management report is no easy job. Besides a willingness to be frank and open, you need the ability to present the complex realities of business accurately and clearly. The people writing and editing the report have to ensure that the text is relevant, truthful and clearly understandable. And above all, they must be masters of the language. 


\section{The management's view}

The secret to all this is so-called narrative reporting. Narrative reporting can be defined as a verbal commentary from management that accompanies the financial statements. This component of the report is often referred to as the management report or management discussion, but the importance of language in the process is best captured by the term "narrative reporting". The idea is that management must explain the business to readers in its own words, from its own perspective, and from the basis of its own knowledge and information. This requires a willingness to be open and frank. Transparency means that all the information management will communicate externally should be consistent with its internal management reporting. The management report should contain the following:

Information on the context of the business that provides a deeper insight into the company's position, at present and in the future

Additional information on financial and non-financial performance

Forward-looking information to help evaluate likely future performance

Information on the key performance indicators (KPIs) that the company utilizes as an aid to manage for value.

The management report should give reasons for changes that have occurred on the financial and operational level. Investors, financial analysts, business journalists, staff, customers and suppliers also have a vested interest in the way the company's market acceptance is developing, including productivity, the way costs are developing, profitability, innovation, the company's financial situation, customer loyalty, and employee satisfaction. Additionally, the management report should list the most important market and industry trends and discuss their implications.

\section{Swiss academic research}

For more than a decade, the Swiss Banking Institute, (under the leadership of Professor Rudolf Volkart,) has been carrying out intensive research on value reporting, a corresponding checklist has been drawn up based on criteria and examples of best practice. As the introductory remarks to the checklist show, the institute's researchers have come to similar conclusions to that of PricewaterhouseCoopers: 
"[Value reporting] goes way beyond the information provided in standard annual financial statements. In addition to information that tends to be related to results and oriented to the past, value reporting should also contain forward-looking information related to value generation. In particular this includes prospective key performance indicators of a non-financial type."[4]

The checklist is intended as a supplementary to a company's end of year financial statements. Thus it contains non-financial and forward-looking indicators as well. For the Swiss Banking Institute, explanations from management are particularly important. Background information on products, markets, strategic success factors and corporate governance should be given and they should analyse trends and explain changes in the figures and investments. This enables readers to interpret the figures and evaluate the company within the context of its industry.

\section{A challenging task}

Value reporting is a great opportunity for companies seeking more convincing and credible ways of reporting on their business. It's a means of communicating a whole range of information that is difficult or impossible to quantify. It is an opportunity for discussing alternative strategies, running through scenarios, and discussing subjective probabilities. This primarily verbal form of reporting is a way of making a company's value generation process more transparent. Nevertheless, good value reporting is a challenge:

The report has to be presented in such a way that the reader understands the company's business. The company's financial performance is evidently the result of its business activities and the impact of special events. Any analysis must first identify and clarify the connections between the company's business, financial results and the influence of other events, regardless of whether they're the result of the company's own strategic decisions or are based more on a macroeconomic basis. Making forecasts means translating future business activities and events into figures. This means one must understand the connections between the company's decisions, external influences and resulting financial effects.

Readers expect a forward-looking approach. On the other hand, making forecasts and predictions is a tricky business. If ones forecasts turn out wrong, the credibility of management is damaged, or in the worst case one might risk legal action. For this reason management should avoid the temptation of making quantitative financial predictions. Instead conclusions should be derived from the current and historical data. Indicators must be 
drawn on and internal plans disclosed. This would include details of the company's key success factors and an assessment of opportunities and risks.

Management should describe and explain its assessment of the business situation. Since it is management that has the most information and holds responsibility for deciding on future business policy, this information (provided it is truthful and reliable) is an invaluable aid to interpreting the report. It also allows readers to assess the quality of management on the basis of their own account of the business.

Commenting on financial and non-financial data can be a great challenge for management. Some companies have faced the challenge, and have used narrative reporting to substantially improve the quality of their business reports. For every best example, there are many instances of reports where the discussion and analysis of the company's business are superficial and onesided, and more confusing than illuminating.

The truth is that transparent reporting is within the management's own interest. There are two reasons. Firstly, any weaknesses in the company's value management or internal management system are exposed as soon as work starts on preparing the relevant documentation and composing of the report. This is a valuable source of feedback that can be used to improve the company's management instruments. Secondly, value reporting helps management reduce information asymmetries, thus avoiding any conflict with its stakeholders. Value reporting gives management extra credibility that will work in its favour in times of crisis or conflict. The mere fact that a company makes the effort to provide this type of information is an advantage in the financial world, and helps build stakeholder trust.

\section{Conclusion}

The rules and regulations governing financial reporting are becoming increasingly complex. However, far from reducing the importance of language in corporate reporting, the trend is actually making language more vital. If reporting is to build trust, companies have to build understanding amongst all their stakeholder groups. This, of course, requires words. A verbal narrative describing how a company manages for value, and detailed financial statements, are two complementary poles of transparent, credible corporate reporting. 


\section{Author}

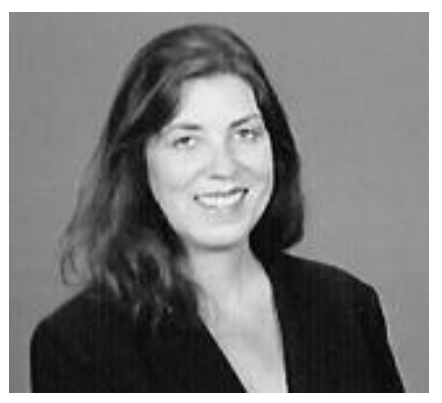

Business journalist Gabriele Moll holds a Ph.D. in economics. She owns and manages Graf Moll \& Partner (www.grafmoll.ch), a Zurich-based corporate publishing agency specialising in financial communication, in particular creating and producing high-quality editorial concepts and text for annual reports and other corporate publications. Born in Cologne, Gabriele Moll has lived and worked in Zurich for twenty years. Her Ph.D. dissertation contributed to the research on value reporting done by the Swiss Banking Institute at the University of Zurich.

[1] Mueller, Gerhard G.: The Evolving (New) Model of Business Reporting, in: Börsig/Coenenberg: Controlling und Rechnungswesen im internationalen Wettbewerb, Stuttgart 1998.

[2] Beaver William L: Financial Reporting: An Accounting Revolution, 3rd edition, Upper Saddle River/New Jersey 1998.

[3] Wright, Philip D./Keegan, Daniel P.: Pursuing Value: The Emerging Art of Reporting on the Future, published by Price Waterhouse LLP, 1997

[4] Labhart, Peter A./Volkart, Rudolf: 1. Beitrag im Fokus der Wirtschaft "Value Reporting - zentraler Stein im Shareholder-ValueMosaik", in: Neue Zürcher Zeitung, Vol. 221, No. 123, 27/28 May 2000.

This article was uploaded to http://www.languageatwork.eu in July of 2009 and published under a "Creative Commons license Attribution Non-commercial (by-nc)" for more information please go to: http://creativecommons.org/about/license/ 